\title{
KARAKTERISTIK RUMAH TANGGA USAHA TANI DAN KELAYAKAN USAHA TANI KUBIS DI SUMATERA UTARA
}

\section{Characteristics Of Household Business Housing And Feasibility Of Cabbage Business In Sumatera Utara}

\author{
Rita Herawaty Br Bangun' \\ Fungsional Statistisi BPS Provinsi Sumatera Utara \\ Jalan Asrama No 179 Medan \\ Email: rita.bangun@bps.go.id
}

\begin{abstract}
Cabbage is one of the vegetable horticultural commodities that is beneficial to human health because it contains many vitamins and minerals. The purpose of this study was to analyze the characteristics of cabbage farming households and analyze the feasibility of cabbage farming. The data used in this study are primary data which are the results of the Horticultural Crops Cost Structure Survey (SOUH) conducted in 2018 and secondary data from publications published by BPS. This research uses descriptive qualitative and quantitative analysis. The characteristics of cabbage farming households viewed from the age aspect show that most cabbage farmers are in productive age. Viewed from the aspect of education, the education level of cabbage farmers is still relatively low, most of the cabbage farmers in North Sumatra have junior high school education downwards at 57.87 percent while those with high education are diploma and undergraduate level at 10.79 percent. The cabbage farming financing in North Sumatra comes from its own cost of 78.47 percent while financing comes from loans amounting to 21.53 percent. Sales of most products are sold directly to collectors, which is 93.77 percent. The role of extension workers and institutions is still low, with 93.30 percent claiming they have never received counseling and 98.32 percent of households are not members of the KUD. Based on the analysis of $R / C$, cabbage is feasible because it is economically profitable.
\end{abstract}

Keywords: cabbage, characteristics, farm feasibility

\begin{abstract}
ABSTRAK
Kubis merupakan salah satu komoditas hortikultura sayuran yang bermanfaat bagi kesehatan tubuh manusia karena banyak mengandung vitamin dan mineral. Tujuan penelitian ini adalah untuk menganalisis karakteristik rumah tangga usahatani kubis dan menganalisis kelayakan usahatani kubis. Data yang digunakan dalam penelitian ini adalah data primer yang merupakan hasil dari Survei Struktur Ongkos Usaha Tanaman Hortikultura (SOUH) yang dilaksanakan pada Tahun 2018 dan data sekunder yang berasal dari publikasi yang diterbitkan oleh BPS. Penelitian ini menggunakan analisis deskriptif kualitatif dan kuantitatif. Karakteristik rumah tangga usahatani kubis dilihat dari aspek umur menunjukkan bahwa sebagian besar petani kubis berada di usia produktif. Dilihat dari aspek pendidikan, tingkat pendidikan petani kubis masih tergolong rendah, sebagian besar petani kubis di Sumatera Utara berpendidikan SMP ke bawah yaitu sebesar 57,87 persen sedangkan yang berpendidikan tinggi yaitu tingkat diploma dan sarjana sebesar 10,79 persen. Pembiayaan usaha tani kubis di Sumatera Utara berasal dari biaya sendiri sebesar 78,47 persen sedangkan pembiayaan bersumber dari pinjaman sebesar 21,53 persen. Penjualan hasil produksi terbanyak dijual langsung ke pedagang pengumpul yaitu sebesar 93,77 persen. Peranan penyuluh dan kelembagaan masih rendah, sebanyak 93,30 persen mengaku tidak pernah mendapat penyuluhan dan 98,32 persen rumah tangga tidak menjadi anggota KUD. Berdasarkan analisis R/C kubis layak diusahakan karena menguntungkan secara ekonomis.
\end{abstract}

Kata kunci: kubis, karakteristik, kelayakan usahatani 


\section{PENDAHULUAN}

Pertanian merupakan sektor yang berperan penting dalam perekonomian di Sumatera Utara. Sektor ini berperan sebagai penyumbang terbesar terhadap PDRB Sumatera Utara yaitu sebesar 20,48 persen (BPS, 2020). Sektor pertanian juga berperan sebagi penyedia lapangan kerja, sebanyak 2,37 juta penduduk Sumatera Utara bekerja di sektor ini (BPS, 2020). Hortikultura merupakan salah satu subsektor yang berperan penting dalam sektor pertanian meskipun kontribusinya masih di bawah subsektor perkebunan dan tanaman pangan. Letak geografis Sumatera Utara memberi keuntungan bagi pengembangan pertanian khususnya tanaman hortikultura. Keanekaragaman komoditas tanaman hortikultura memungkinkan untuk tumbuh baik di dataran tinggi dan dataran rendah (BPS, 2015).

Komoditas hortikultura khususnya sayuran dan buah-buahan berperan penting dalam keseimbangan pangan yang dikonsumsi sehingga harus tersedia setiap saat dalam jumlah yang cukup, bermutu baik, aman untuk dikonsumsi dan harga yang terjangkau (BPS, 2015). Komoditas sayuran juga berperan sebagai sumber gizi masyarakat, penghasil devisa negara, dan penunjang kegiatan industri dan pariwisata (Istanto et al., 2016). Menurut Handayani (2019) komoditas hortikultura tergolong komoditas komersial bernilai ekonomi tinggi sehingga harus diproduksi secara efisien untuk dapat bersaing di pasar. Kubis merupakan salah satu komoditas sayuran yang paling banyak diusahakan juga merupakan salah satu komoditas ekspor di Sumatera Utara. Kubis termasuk salah satu komoditas unggulan hortikultura dan mempunyai potensi untuk dikembangkan. Berdasarkan data yang dikeluarkan oleh Badan Pusat Statistik (BPS) kubis menghasilkan produksi terbesar di antara komoditas sayuran lainnya (BPS, 2020). Kubis merupakan salah satu komoditas sayuran yang banyak mengandung vitamin dan mineral yang dibutuhkan oleh tubuh manusia (Nurmala et al., 2016). Selain itu usaha tani kubis banyak diminati karena masa panen tanaman kubis lebih cepat daripada jenis tanaman pangan dan hortikultura lainnya (Ratnasari et al., 2016).

Pengembangan budidaya kubis sebagai sayuran dataran tinggi memerlukan penanganan yang khusus mulai pra sampai pasca panennya. Warni (2017) menjelaskan bahwa perlu penerapan agribisnis dalam usahatani sehingga keuntungan yang diperoleh petani kubis lebih banyak.Usaha tani kubis menghadapi berbagai masalah dalam proses budidayanya. Sampai saat ini kegiatan budidaya kubis di Sumatera Utara masih dilakukan secara tradisional. Permasalahan yang dihadapi oleh petani antara lain penanganan serangan hama dan penyakit pada tanaman, belum optimlanya faktor-faktor produksi dan penanganan panen dan pasca panen. Kurangnya pengetahuan petani dalam kegiatan pemeliharaan juga mempengaruhi pendapatan yang diperoleh (Lubis et al., 2018).

Kajian karakteristik rumah tangga usaha tani terutama petani perlu dilakukan karena setiap upaya pengembangan komoditas pertanian harus memperhatikan aspek sumber daya manusia yang terkait. Penelitian tentang karakteristik petani sudah pernah dilakukan di antaranya adalah penelitian yang dilakukan oleh Marhawati (2019) yang meneliti tentang karakteristik dan tingkat pendapatan usahatani jeruk pamelo di Kabupaten Pangkep. Suswadi \& Sutarno (2017) juga melakukan penelitian tentang karakteristik dan partisipasi petani pada pengembangan usahatani padi organik di Kabupaten Boyolali. Penelitian yang sama juga dilakukan oleh Asih (2009) tentang karakteristik dan tingkat pendapatan bawang merah di Sulawesi Tengah. Berdasarkan uraian di atas maka perlu dilakukan penelitian untuk mengkaji karakteristik rumah tangga usaha tani dan menganalisis kelayakan usahatani kubis. Tujuan dari penelitian ini adalah untuk mengidentifikasi karakteristik rumah tangga usaha tani untuk peningkatan daya saing petani dalam menghadapi pasar global dan menganalisis kelayakan usaha tani kubis.

\section{METODE PENELITIAN}

Penelitian ini merupakan penelitian deskriptif. Penelitian deskriptif adalah penelitian yang dirancang untuk mendeskripsikan fenomena-fenomena yang ada dan dalam penelitian deskriptif tidak ada pengujian hipotesis seperti pada peneltian eksperimen (Linarwati et al., 2016). Nasution (2017) 
menyatakan bahwa peneltian deskriptif berfungsi menerangkan keadaan, gejala atau persoalan yang terjadi dalam masyarakat atau lingkungan.Data yang digunakan dalam penelitian ini adalah data primer dan data sekunder. Data primer bersumber dari hasil Survei Struktur Ongkos Usaha Tanaman Hortikultura (SOUH) yang dilaksanakan pada Tahun 2018 sedangkan data sekunder berasal dari publikasi yang diterbitkan oleh BPS dan instansi terkait. Jumlah sampel rumah tangga yang digunakan dalam SOUH sebanyak 298 rumah tangga usaha tani. Pengambilan sampel dilakukan secara simple random sampling dari rumah tangga usaha tani hasil Survei Pertanian Antar Sensus (SUTAS) pada tahun 2018.

Metode analisis yang digunakan dalam penelitian ini adalah analisis deskriptif kualitatif dan analisis kuantitatif. Analisis kualitatif digunakan untuk memberikan gambaran karakteristik rumah tangga usaha tani kubis di Sumatera Utara yang meliputi kelompok umur petani, tingkat pendidikan, sumber pembiayaan usaha, pemasaran hasil pertanian, dan kendala usaha tani. Analisis kuantitatif digunakan untuk menjelaskan gambaran kelayakan finansial usaha tani kubis. Salah satu ukuran kelayakan usaha adalah analisis return cost ratio $(R / C)$. Analisis return cost ratio $(\mathrm{R} / \mathrm{C})$ merupakan perbandingan antara penerimaan dan biaya (Baru et al., 2015; Hutapea, 2016; Sari et al., 2013; Siregar, 2011). Formulasi $\mathrm{R} / \mathrm{C}$ sebagai berikut :

$$
\mathrm{R} / \mathrm{C}=\frac{T R}{T C} .
$$

Dimana:

$\mathrm{R} / \mathrm{C} \quad$ : Return cost ratio

TR : Total penerimaan

TC : Total ongkos produksi usahatani

Dengan kriteria :

$\mathrm{R} / \mathrm{C}>1$ artinya usahatani layak diusahakan, menguntungkan secara ekonomi

$\mathrm{R} / \mathrm{C} \leq 1$ artinya usahatani tidak layak diusahakan, tidak menguntungkan secara ekonomi.

\section{HASIL DAN PEMBAHASAN}

\section{Perkembangan Komoditas Kubis di Sumatera Utara}

Kubis merupakan salah satu komoditas unggulan pertanian hortikultura di Provinsi Sumatera Utara. Hal ini ditunjukkan dengan kontribusi komoditas tersebut pada produksi hortikultura khususnya komoditas sayur-sayuran. Berdasarkan data Badan Pusat Statistik (BPS), kubis memberikan kontribusi terbesar yaitu 19,76 persen terhadap total produksi sayur-sayuran di Sumatera Utara pada tahun 2019 (BPS, 2020). Produksi kubis sebesar 2,2 juta kuintal, meningkat sebesar 27,02 persen dibandingkan produksi pada tahun 2019. Produksi kubis tumbuh sebesar 7,66 persen per tahun selama kurun waktu tahun 2016 sampai tahun 2019. Peningkatan produksi kubis juga diikuti oleh peningkatan luas panen. Luas panen kubis meningkat 11,24 persen dibandingkan luas panen pada tahun 2018. Luas panen kubis tumbuh sebesar 3,95 persen per tahun selama kurun waktu tahun 2017 sampai tahun 2019. Hal ini menunjukkan bahwa kubis merupakan komoditas yang berperan penting dalam pembangunan pertanian di Sumatera Utara karena kubis merupakan salah satu komoditas yang mempunyai nilai ekonomi dan potensi pengembangan. Menurut Tsurayya \& Kartika (2015) komoditas unggulan merupakan komoditas yang layak diusahakan karena memberikan keuntungan kepada petanidan berdampak pada penyerapan tenaga kerja serta perekonomian daerah. Komoditas kubis dibudidayakan di sebagian besar di wilayah Sumatera Utara. Daerah yang menjadi sentra pertanaman kubis adalah Kabupaten Karo, Kabupaten Simalungun, dan Kabupaten Samosir (BPS, 2020). Kabupaten Karo memberikan kontribusi terbesar pada produksi kubis sebesar 67,35 persen diikuti Kabupaten Simalungun sebesar 25,37 persen, dan Kabupaten Samosir 3,93 persen terhadap total produksi kubis di Provinsi Sumatera Utara. 


\section{Karakteristik Rumah Tangga Usaha Tani Kubis}

Karakteristik rumah tangga usaha tani merupakan faktor-faktor yang mendukung keberhasilan usaha pertanian dalam jangka waktu tertentu (Haloho et al., 2013). Karakteristik rumah tangga usaha tani kubis dapat dijelaskan sebagai berikut:

\section{a. Umur Petani}

Umur merupakan salah satu faktor keberhasilan petani dalam menjalankan usaha pertaniannya. Menurut Samarpitha et al., (2016) umur berpengaruh terhadap resiko petani mengambil sikap dan inovasi dalam mengadopsi teknologi baru. Hastang \& Aslina (2014) juga berpendapat usia produktif merupakan peluang untuk peningkatan produksi dan pendapatan usaha pertanian. Hasil penelitian menunjukkan bahwa petani kubis di Sumatera Utara sebanyak 23,20 persen berumur di atas 55 tahun, 35,11 persen berumur antara 45-54 tahun, 27,89 persen berumur antara 35-44 tahun dan 13,80 persen berumur antara 25-34 tahun. Hasil penelitian ini menunjukkan bahwa petani kubis di Sumatera Utara berada di usia produktif. Karakteristik umur tersebut mendukung usaha pertanian yang diusahakan karena pada kategori umur tersebut petani masih memiliki kemampuan fisik yang kuat dan mempunyai kemampuan untuk pengembangan usaha pertaniannya. Solikin et al., (2018) berpendapat bahwa usia akan sangat mempengaruhi produktifitas kerja karena lebih dominan mengandalkan kekuatan fisik. Faktor umur seseorang ikut menentukan tingkat partisipasi kerjanya dalam mencari nafkah. Makin bertambah usia seseorang makin bertambah pula partisipasinya tetapi akan menurun pula pada usia tertentu sejalan dengan faktor kekuatan fisik yang makin menurun pula. Faktor usia akan sangat berpengaruh pada pekerjaan yang sangat mengandalkan kekuatan dan kemampuan fisik tenaga kerja.

\section{b. Tingkat Pendidikan}

Faktor pendidikan diharapkan dapat membantu masyarakat dalam upaya peningkatan produksi dan produktifitas ternak yang dipelihara. Tingkat pendidikan yang memadai akan berdampak pada peningkatan kinerja dan kemampuan manajemen usaha peternakan yang dijalankan (Hastang \& Aslina, 2014). Menurut Haloho et al., (2013) pendidikan akan menambah pengetahuan dan keterampilan sehingga akan meningkatkan poduktifitas kerja yang akan menentukan keberhasilan usahanya. Tingkat pendidikan petani kubis di Sumatera Utara masih tergolong rendah. Hasil penelitian menunjukkan bahwa sebagian besar petani kubis di Sumatera berpendidikan SMP ke bawah yaitu sebesar 57,87 persen sedangkan yang berpendidikan tinggi yaitu tingkat diploma dan sarjana sebesar 10,79 persen. Rendahnya tingkat Pendidikan yang dimiliki oleh petani akan mempengaruhi pola piklr petani dalam pengembangan usaha pertaniannya. Iriyani \& Nugrahani, (2017) menjelaskan bahwa tingkat pendidikan dapat berpengaruh terhadap kecepatan seorang petani dalam mengadopsi teknologi baru yang dapat menambah pengetahuan dalam pengembangan usaha pertaniannya. Asih (2009) dalam penelitiannya tentang karakteristik usaha tani bawang merah di Sulawesi Tengah menyimpulkan bahwa usia dan tingkat pendidikan mempengaruhi petani dalam mengambil keputusan dalam menjalankan usaha pertaniannya.

\section{c. Modal Usaha Tani}

Modal merupakan salah satu faktor penting dalam menunjang pengembangan usaha pertanian. Menurut Mulyaqin et al., (2016) modal merupakan faktor produksi yang sangat penting dalam produksi pertanian. Berdasarkan hasil penelitian, pembiayaan usaha tani kubis di Sumatera Utara berasal dari biaya sendiri. Persentase rumah tangga tani kubis yang sumber pembiayaan usaha taninya dengan biaya sendiri sebesar 78,47 persen. Tingginya persentase sumber pembiayaan usaha tani kubis dengan modal sendiri menunjukkan bahwa petani kubis di Sumatera Utara memiliki kemampuan secara finansial dalam pembiayaan usaha pertaniannya. Gofur et al., (2014) menjelaskan bahwa dampak positif dari modal usaha sendiri adalah terpenuhinya modal usaha dengan cepat dan dapat merasakan keuntungan sepenuhnya tanpa adanya beban biaya setiap bulannya yang harus ditanggulangi. Selain dari modal sendiri, sumber pembiayaan usaha tani petani kubis di Sumatera Utara berasal dari pembiayaan dari pinjaman sebesar 21,53 persen dimana 14,55 persen adalah pinjaman 
dengan bunga dan 6,98 pinjaman tanpa bunga. Petani yang sumber pembiayaan usahanya dengan pinjaman bunga lebih memilih yang sumbernya dari bank yaitu sebanyak 17 persen.

\section{d. Pemasaran Hasil Pertanian}

Pemasaran merupakan hal yang paling penting dalam kegiatan budidaya usaha pertanian (Asmarantaka et al., 2018). Ratnasari et al., (2016) dalam penelitiannya menjelaskan bahwa pemasaran merupakan hal yang sangat penting setelah selesainya proses produksi pertanian khususnya untuk tanaman hortikultura karena produk hortikultura mempunyai sifat yang tidak tahan lama. Hasil penelitian menunjukkan bahwa sebagian besar petani kubis menjual hasil produksinya ke pedagang pengumpul yaitu sebanyak 93,77 persen sedangkan sisanya ke kelompok tani yaitu 0,87 persen, pasar sebesar 4,39 persen dan lainnya sebesar 0,96 persen. Petani lebih memilih untuk menjual produksi usaha pertaniannya langsung ke pedagang pengumpul karena pada saluran pemasaran ini petani tidak mengeluarkan biaya apapun. Hasil penelitian ini mendukung penelitian yang dilakukan oleh Ratnasari et al., (2016) yang meneliti tentang pemasaran dan strategi pengembangan usahatani kubis di Desa Sumberejo. Hasil penelitian ini juga mendukung penelitian yang dilakukan oleh Pakpahan \& Damanik (2018) yang meneliti tentang pemasaran komoditi belimbing.

\section{e. Partisipasi Kelembagaan Usaha Tani}

Kelembagaan petani dan penyuluhan merupakan faktor penting dalam pengembangan dan peningkatan usaha pertanian. Anantanyu (2011) menjelaskan bahwa keberadaan kelembagaan petani berkontribusi dalam akselerasi pengembangan sosial ekonomi dan aksebilitas informasi petani dan memudahkan pemangku kepentingan dalam memfasilitasi dan memberikan penguatan pada petani. Aini \& Nadida (2014) juga menjelaskan bahwa kelembagaan petani merupakan bagian pranata social yang memfasilitasi interaksi social dalam komunitas petani.

Hasil penelitian menunjukkan bahwa dari sejumlah sampel rumah tangga usaha tani kubis di Sumatera Utara sebanyak 93,30 persen mengaku tidak pernah mendapat penyuluhan sedangkan 6,70 persen rumah tangga mendapat penyuluhan. Hasil penelitian juga menunjukkan bahwa sebanyak 98,32 persen rumah tangga tidak menjadi anggota KUD. Faktor yang mendukung ketidakikutsertaan petani menjadi anggota KUD adalah belum adanya KUD atau Koperasi Tani di wilayah petani. Hasil dari penelitian tersebut menunjukkan bahwa masih rendahnya peranan kelembagaan pertanian di Sumatera Utara. Penelitian yang dilakukan oleh Syabrina et al., (2013) menyimpulkan bahwa penyelenggaraan penyuluhan pertanian tidak efisien dan efektif karena kelembagaan yang beragam dan tidak adanya harmonisasi antar instansi. Rendahnya partisipasi petani dalam kelembagaan menjadi isyu penting bagi pembangunan pertanian di Sumatera Utara. Pengembangan kelembagaan pertanian sangat penting untuk peningkatan kapasitas petani agar mampu bersaing dan tangguh dalam menghadapi persaingan global (Veronice et al., 2018).

\section{Kelayakan Usaha Tani Kubis}

Keberhasilan usahatani kubis di Sumatera Utara ditunjukkan oleh hasil analisis penerimaan atas biaya yang dikeluarkan $(\mathrm{R} / \mathrm{C})$. Analisis usahatani ini menunjukkan berapa penerimaan yang akan diperoleh oleh petani dari setiap biaya yang dikeluarkan untuk kegiatan usaha tani kubis. Pengeluaran dalam usahatani kubis terdiri dari biaya produksi, upah tenaga kerja dan pengeluaran lainnya. Biaya produksi yang dikeluarkan untuk budidaya komoditas kubis per hektar per musim tanam sebesar 23,33 juta rupiah. Upah tenaga kerja merupakan komponen pengeluaran terbesar yaitu sebesar 9,66 juta rupiah atau sekitar 41,42 persen dari total biaya produksi (BPS, 2019). Penerimaan yang diterima oleh petani per hektar per musim tanam sebesar 29,31juta rupiah. Penerimaan yang diperoleh dari usahatani kubis bergantung pada jumlah produksi yang dihasilkan. Menurut Baru et al., (2015) penerimaan dipengaruhi oleh besar kecilnya produksi dan mutu produksi cabai. Secara lengkap rincian penerimaan dan biaya dapat dilihat pada Tabel 1. 
Pendapatan merupakan salah satu alat ukur keberhasilan usaha budidaya pertanian. Menurut Siregar (2011) pendapatan dari usahatani memberikan gambaran mengenai keberhasilan usahatani. Pendapatan usahatani yang diperoleh adalah selisih antara penerimaan dengan biaya yang dikeluarkan untuk kegiatan budiaya komoditas pertanian. Hasil penghitungan menunjukkan pendapatan yang diterima oleh petani kubis di Sumatera Utara per musim tanam sebesar 5,98 juta rupiah. Hal ini menunjukkan bahwa usahatani kubis di Sumatera Utara memberi keuntungan bagi petani yang cukup besar. Hasil penghitungan kelayakan usahatani dengan revenue cost ratio $(R / C)$ tingkat kelayakan usahatani cabai besar sebesar 1,26 yang menggambarkan dengan mengeluarkan biaya sebesar 1 rupiah maka petani akan memperoleh penerimaan sebesar 1,26 rupiah. Hal ini menunjukkan bahwa usahatani cabai besar di Provinsi Sumatera Utara layak untuk diusahakan karena menguntungkan secara ekonomis. Hasil penelitian ini mendukung penelitian yang dilakukan oleh Huda et al., (2015) yang meneliti tentang pendapatan dan resiko usahatani kubis pada lahan kering dan lahan sawah tadah hujan di Kecamatan Gisting. Penelitian yang dilakukan oleh Wibisono (2011) juga menyimpulkan bahwa kubis merupakan komoditas yang layak dan menguntungkan untuk dibudidayakan oleh petani di Kecamatan Sawangan. Nurmala et al., (2016) dalam penelitiannya juga menyimpulkan bahwa usahatani kubis putih di Desa Cibeureum layak untuk diusahakan karena menguntungkan secara ekonomis.

\section{SIMPULAN DAN SARAN}

Karakteristik petani kubis di Sumatera Utara secara umum berada di usia yang produktif namun memiliki tingkat pendidikan yang masih rendah. Sumber pembiayaan untuk pengembangan budidaya kubis berasal dari modal sendiri yang menunjukkan kemampuan petani kubis secara ekonomis dan ketidakpercayaan terhadap lembaga keuangan karena alasan administrasi yang sulit dan berbelit belit. Pola pemasaran kubis sebagian besar langsung ke pedagang pengumpulan karena mudah dan bebas biaya. Partisipasi petani dalam kelembagaan masih sangat rendah dan kurangnya peranan penyuluh dalam pemberdayaan petani di Sumatera Utara. Secara ekonomis komoditas kubis layak diusahakan karena memberikan keuntungan secara finansial bagi petani di Sumatera Utara. Peningkatan pendapatan usahatani kubis dengan lebih mengoptimalkan faktor-faktor produksi yang meliputi penggunaan benih, pupuk dan pestisida yang tepat guna serta optimalisasi lahan. Perlu adanya dukungan dari pemerintah daerah terutama dari Dinas Pertanian khususnya mengenai teknik budidaya untuk meningkatkan pengetahuan dan keterampilan petani yang dapat meningkatkan produksi dan pendapatan petani. Pemberdayaan petani perlu ditingkatkan dengan pembentukan KUD dan peningkatan peran penyuluh pertanian untuk peningkatan daya saing.

\section{DAFTAR PUSTAKA}

Aini, H. N., Prasmatiwi, F. E., \& Sayekti, W. D. (2015). Analisis Pendapatan dan Risiko Usahatani Kubis pada Lahan Kering dan Lahan Sawah Tadah Hujan di Kecamatan Gisting Kabupaten Tanggamus. Jurnal Ilmu-IImu Agribisnis, 3(1), 1-9.

Aini, Y. N., \& Nadida, Z. (2014). Analisis Kelembagaan Petani Dalam Mendukung Keberfungsian Infrastruktur Irigasi (Studi Kasus: Daerah Irigasi Batang Anai, Sumatera Barat). Jurnal Sosek Pekerjaan Umum, 6(3), 140-221.

Anantanyu, S. (2011). Kelembagaan Petani: Peran Dan Strategi Pengembangan Kapasitasnya. SEPA, 7(2), 102-109.

Asih, D. N. (2009). Analysis of Characteristics and Earning Level of Shallots Farming System in Central Sulawesi. AGROLAND, 16(1), 53-59.

Asmarantaka, R. W., Atmakusuma, J., Muflikh, Y. N., \& Rosiana, N. (2018). Konsep Pemasaran Agribisnis : Pendekatan Ekonomi Dan Manajemen. Jurnal Agribisnis Indonesia, 5(2), 151-172

Baru, H. G., Tariningsih, D., \& Tamba, I. M. (2015). Analisis PENDAPATAN Usahatani Cabai Di Desa Antapan (Studi Kasus Di Desa Antapan Kecamatan Baturiti Kabupaten Tabanan). AGRIMETA, 5(10), 14-20.

BPS. (2015). Analisis Rumah Tangga Usaha Hortikultura di Indonesia. Jakarta: Badan Pusat Statistik.

BPS. (2019). Hasil Survei Struktur Ongkos Usaha Tanaman Hortikultura (SOUH). Medan: BPS Provinsi Sumatera Utara. 
BPS. (2020). Provinsi Sumatera Utara Dalam Angka 2020. Medan: Badan Pusat Statistik Provinsi Sumatera Utara.

Gofur, M. A., Fadah, I., \& Surnani. (2014). Analisis Modal Kerja Petani Cabai Merah Besar di Kecamatan Sempu Kabupaten Banyuwangi. Jurnal Artikel IImiah Mahasiswa, 1(1), 1-5.

Haloho, R. D., Santoso, S. I., \& Marzuki, S. (2013). Efisiensi Usaha Peternakan Sapi Perah Di Kabupaten Semarang. AGROMEDIA, 31(2), 1-8.

Handayani, T. A. (2019). Analisis Pendapatan, Risiko, Dan Efisiensi Teknis Usahatani Kubis Di Kecamatan Sumberejo Kabupaten Tanggamus (Universitas Lampung).

Hastang, \& Aslina, A. (2014). Analisis Keuntungan Peternak Sapi Potong Berbasis Peternakan Rakyat Di Kabupaten Bone. Jurnal IImiah IImu-IImu Peternakan, 1(1), 240-252.

Hutapea, K. P. (2016). Analisis Pendapatan Cabai Merah Keriting ( Capsicum Annum L ). ( Studi Kasus : Di Desa Bandar Tongah Kecamatan Bandar Kabupaten Simalungun Provinsi Sumatera Utara. Majalah IImiah Politeknik Mandiri Bina Prestasi, 5(2), 167-173.

Iriyani, D., \& Nugrahani, P. (2017). Karakteristik Petani Sayuran Periurban Kota Surabaya. Prosiding Seminar Nasional Tahunan Matematika, Sains, Dan Teknologi., 105-118.

Istanto, Roessali, W., \& Setiadi, A. (2016). Analisis Pemasaran Kubis (Brassica oleracea L. var. cagitata L.) di Sub Terminal Agribisnis (STA) Jetis Kabupaten Semarang. Mediagro, 12(2), 1-10.

Linarwati, M., Fathoni, A., \& Minarish, M. M. (2016). Studi Deskriptif Pelatihan Dan Pengembangan Sumberdaya Manusia Serta Penggunaan Metode Behavioral Event Interview Dalam Merekrut Karyawan Baru Di Bank Mega Cabang Kudus. Journal of Management, 2(2), 1-8.

Lubis, M. R. S., Sihombing, L., \& N, S. K. (2018). Analisis Komparasi Kebutuhan Biaya Pemeliharaan Normatif Komoditas Kubis Dengan Praktek Pelaksanaanya Di Kabupaten Karo. Journal On Social Economic Of Agriculture And Agribusiness, 9(9), 1-16.

Marhawati. (2019). Analisis Karakteristik dan Tingkat Pendapatan Usahatani Jeruk Pamelo Di Kabupaten Pangkep. JEKPEND: Jurnal Ekonomi Dan Pendidikan, 2(2), 39-46.

Mulyaqin, T., Astuti, Y., \& Haryani, D. (2016). Faktor Yang Mempengaruhi Petani Padi Dalam Pemanfaatan Sumber Permodalan : Studi Kasus Di Kabupaten Serang Provinsi Banten. Seminar Nasional BPTP, 2(1), 2016.

Nasution, L. M. (2017). Statistik Deskriptif. Jurnal Hikmah, 14(1), 49-55.

Nurmala, L., Soetoro, \& Noormansyah, Z. (2016). Analisis Biaya, Pendapatan dan RC Usahatani Kubis. Jurnal Ilmiah Mahasiswa Agroinfo Galuh, 2(2), 97-102.

Pakpahan, H. T., \& Damanik, Y. C. P. (2018). Analisis Pemasaran Komoditi Belimbing. AGRIBEST, 3(2), 139-157.

Ratnasari, M., Hartadi, R., \& Ridjal, J. A. (2016). Analisis Pemasaran Dan Strategi Pengembangan Usahatani Kubis Di Desa Sumberejo Kecamatan Ambulu Kabupaten Jember. AGRITROP, 14(1), 66-79.

Samarpitha, A., Vasudev, N., \& Suhasini, K. (2016). Socio-economic Characteristics of Rice Farmers in the Combined State of Andhra Pradesh. Asian Journal of Agricultural Extension, Economics \& Sociology, 13(1), 1-9.

Sari, R. U., Wicaksono, A., \& Utami, D. P. (2013). Analisis Efisiensi Usahatani Kubis (Brassica Oleracea) Di Desa Sukomakmur Kecamatan Kajoran Kabupaten Magelang. Surya Agritama, 2(1), $1-10$.

Siregar, N. M. (2011). Analisis Pendapatan Usaha Tani dan Faktor-Faktor yang Mempengaruhi Produksi Cabai Merah Keriting di Desa Citapen, Kecamatan Ciawi, Kabupaten Bogor. Institut Pertanian Bogor.

Solikin, N., Hartono, B., Fanani, Z., \& Ihsan, M. N. (2018). Tingkat Partisipasi dan Kesejahteraan Peternak Sapi Potong Di Kabupaten Kediri. Jurnal Nusantara Aplikasi Manajemen Bisnis, 3(2), 81-91.

Suswadi, \& Sutarno. (2017). Analisa Karakteristik Dan Partisipasi Petani Pada Pengembangan Usaha Tani Padi Organik (Oryza Sativa, L.)Di Kabupaten Boyolali. AGRINECA, 17(2), 1-17.

Syabrina, E., Hakim, D. B., \& Tonny, F. (2013). Analisis Kelembagaan Penyuluhan Pertanian Di Provinsi Riau. Jurnal Manajemen Pembangunan Daerah., 5(1), 32-46.

Tsurayya, S., \& Kartika, L. (2015). Kelembagaan Dan Strategi Peningkatan Daya Saing Komoditas Cabai Kabupaten Garut. Jurnal Manajemen Dan Agribisnis, 12(1), 1-12.

Veronice, Helmi, Henmaidi, \& Arif, E. (2018). Pengembangan Kapasitas dan Kelembagaan Petani Kecil Di Kawasan Pertanian Melalui Pendekatan Manajemen Pengetahuan. Journal of Applied Agricultural Science and Technology, 2(2), 1-10.

Warni, T. (2017). Analisis Produksi Usahatani Kubis Di Kecamatan Kejajar Kabupaten Wonosobo. Universitas Muhammadiyah Purworejo.

Wibisono, H. (2011). Analisis Efisiensi Usahatani Kubis. Universitas Diponegoro. 


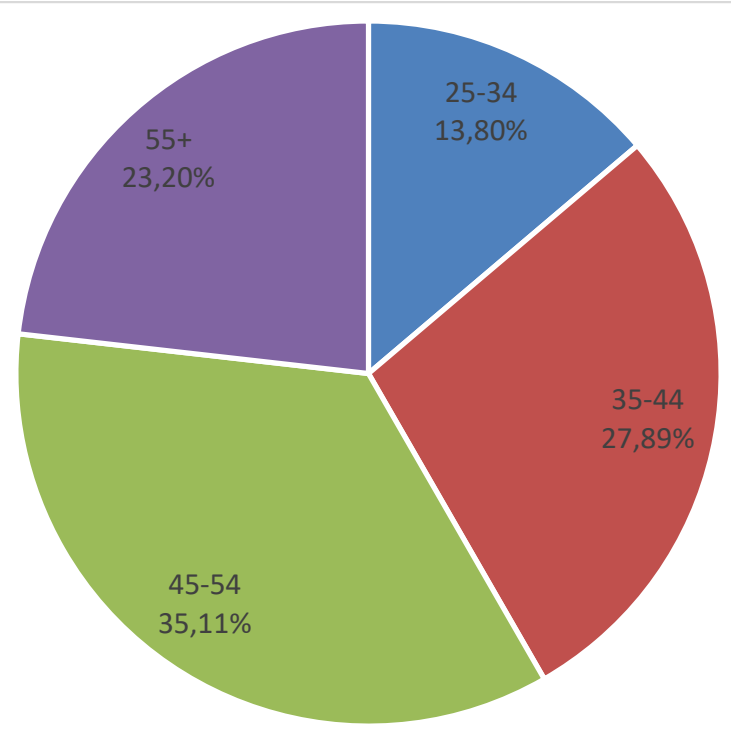

Gambar 1. Persentase Petani Kubis menurut Kelompok Umur di Sumatera Utara Sumber: BPS Provinsi Sumatera Utara, 2019

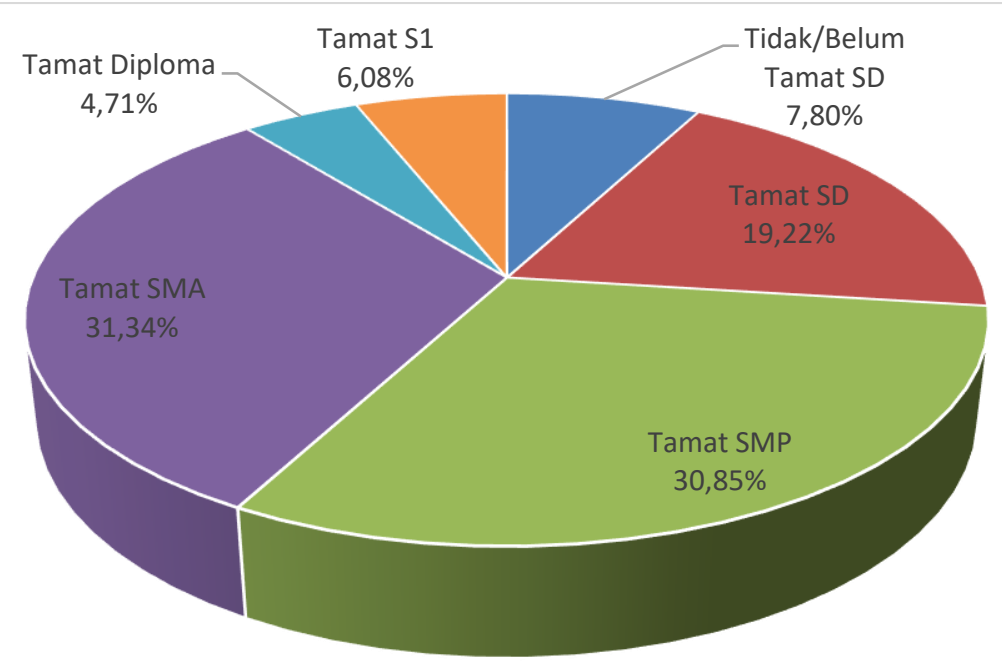

Gambar 2. Persentase Petani Kubis di Sumatera Utara menurut Tingkat Pendidikan Sumber: BPS Provinsi Sumatera Utara, 2019 


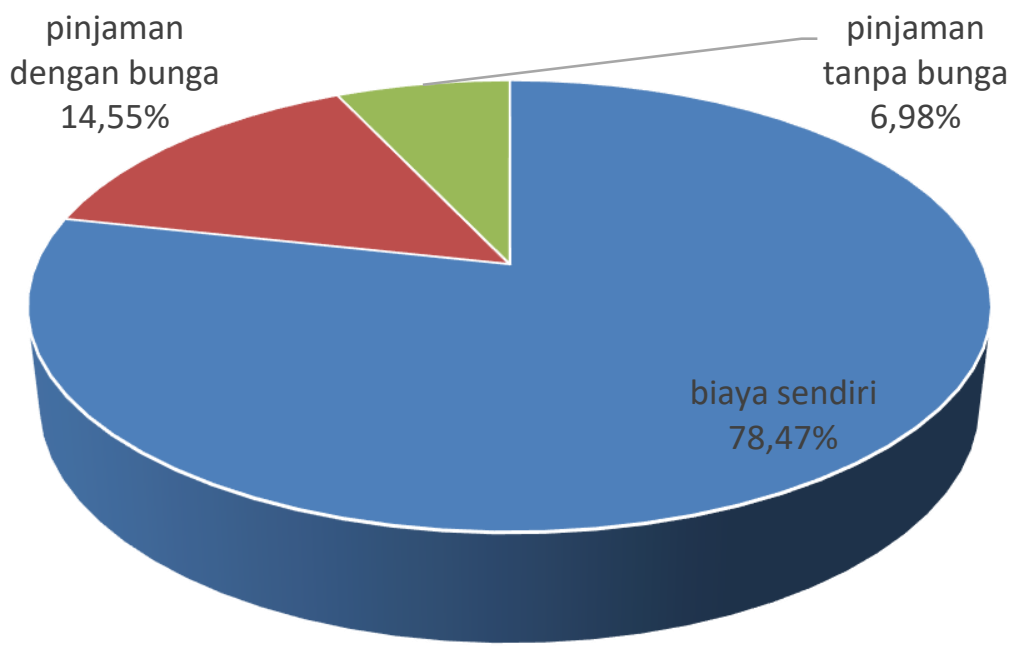

Gambar 3. Persentase Rumah Tangga Usaha Tani Kubis menurut Sumber Modal Usaha di Sumatera Utara

Sumber: BPS Provinsi Sumatera Utara, 2019

Tabel 1. Penerimaan dan Biaya Produksi Tanaman Cabai Besar per hektar per musim tanam di Provinsi Sumatera Utara Tahun 2018

\begin{tabular}{rrr}
\hline No & Uraian & Nilai (000 Rp) \\
\hline$(1)$ & $(2)$ & $(3)$ \\
\hline 1. & Total Penerimaan & $29.312,0$ \\
\hline 2. & Total Biaya Produksi & 23330,3 \\
\hline Benih & 1762,4 \\
\hline Pupuk & 5753,6 \\
\hline Pestisida/Fungisida & 1861,9 \\
\hline Bahan Bakar & 122,0 \\
\hline Listrik & 16,6 \\
\hline Jaring pelindung & 0,1 \\
\hline Mulsa & 137,3 \\
\hline Wadah, Polibag, Ajir, Tali & 49,1 \\
\hline Tenaga Kerja & 9663,2 \\
\hline Sewa Lahan & 2458,1 \\
\hline Pengeluaran lainnya & 1506,2 \\
\hline R.C & 1,26 \\
\hline
\end{tabular}

Sumber: BPS Provinsi Sumatera Utara, 2019 